\title{
EIF2B1 wt Allele
}

National Cancer Institute

\section{Source}

National Cancer Institute. EIF2B1 wt Allele. NCI Thesaurus. Code C53134.

Human EIF2B1 wild-type allele is located in the vicinity of $12 \mathrm{q} 24.31$ and is approximately $13 \mathrm{~kb}$ in length. This allele, which encodes translation initiation factor elF-2B subunit alpha protein, is involved in the regulation of protein elongation. Point mutations in the gene are linked to leukoencephalopathy with vanishing white matter. 